\title{
Immunohistochemical visualization of mouse interneuron
}

\section{subtypes [version 1; peer review: 2 approved, 1 approved with}

\section{reservations]}

\author{
Simon Molgaard1-4, Maj Ulrichsen ${ }^{1,4}$, Simon Boggild1,2, Marie-Louise Holm¹, \\ Christian Vaegter ${ }^{1,4}$, Jens Nyengaard ${ }^{1,2}$, Simon Glerup $1,3,4$
}

\author{
${ }^{1}$ The Lundbeck Foundation Research Center MIND, Department of Biomedicine, Aarhus University, Aarhus, 8000 C, Denmark \\ 2Stereology and Electron Microscopy Laboratory, Department of Clinical institute, Aarhus University, Aarhus, 8000 C, Denmark \\ ${ }^{3}$ Department of Neuroscience, Mayo Clinic, Jacksonville, FL, FL 32224, USA \\ ${ }^{4}$ Danish Research Institute of Translational Neuroscience DANDRITE, Aarhus, 8000, Denmark
}

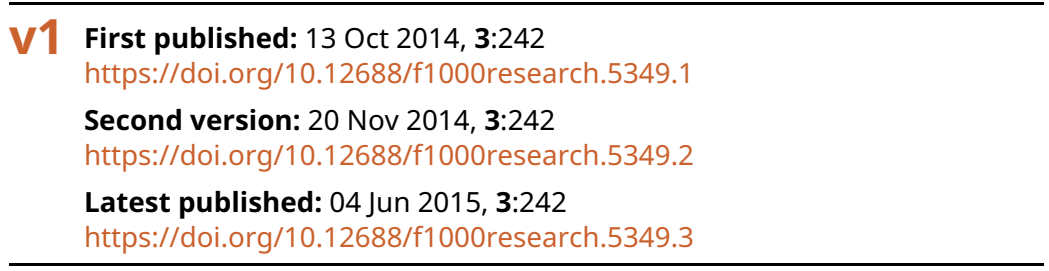

\section{Abstract}

The activity of excitatory neurons is controlled by a small, but highly diverse population of inhibitory interneurons. These cells show a high level of physiological, morphological and neurochemical heterogeneity, and play highly specific roles in neuronal circuits. In the mammalian hippocampus, these are divided into 21 different subtypes of GABAergic interneurons based on their expression of different markers, morphology and their electrophysiological properties. Ideally, all can be marked using an antibody directed against the inhibitory neurotransmitter GABA, but parvalbumin, calbindin, somatostatin, and calretinin are also commonly used as markers to narrow down the specific interneuron subtype. Here, we describe a journey to find the necessary immunological reagents for studying GABAergic interneurons of the mouse hippocampus. Based on web searches there are several hundreds of different antibodies on the market directed against these four markers. Searches in the literature databases allowed us to narrow it down to a subset of antibodies most commonly used in publications. However, in our hands the most cited ones did not work for immunofluorescence stainings of formaldehyde fixed tissue sections and cultured hippocampal neurons, and we had to immunostain our way through thirteen different commercial antibodies before finally finding a suitable antibody for each of the four markers. The antibodies were evaluated based on signal-to-noise ratios as well as if positive cells were found in layers of the hippocampus where they have previously been described. Additionally, the antibodies were also tested on sections from mouse spinal cord with similar criteria for specificity of

\section{Open Peer Review}

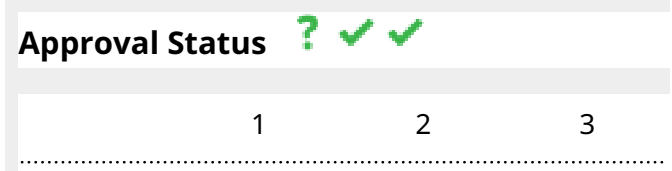

version 3

(revision)

04 Jun 2015

version 2

(revision)

20 Nov 2014

version 1

13 Oct 2014

1. Sally Lowell, University of Edinburgh,

Edinburgh, UK

2. Tomi PJ Rantamäki, University of Helsinki,

Helsinki, Finland

3. Mei Yee Leung, St John's Laboratory Ltd., London, UK

Any reports and responses or comments on the article can be found at the end of the article. 
the antibodies. Using the antibodies with a high rating on pAbmAbs, stainings with high signal-to-noise ratios and location of the immunostained cells in accordance with the literature could be obtained, making these antibodies suitable choices for studying the GABAergic system.

Keywords

antibody validation, immunohistochemistry, hippocampus, spinal cord

This article is included in the Antibody

Validations gateway.

Corresponding author: Simon Glerup (glerup@biomed.au.dk)

Competing interests: No competing interests were disclosed.

Grant information: This study was funded by the Lundbeck Foundation, Danish Medical Research Council, Fonden til forskning af sindslidelser and Agnes og Poul Friis Fond.

Copyright: ( 2014 Molgaard S et al. This is an open access article distributed under the terms of the Creative Commons Attribution License, which permits unrestricted use, distribution, and reproduction in any medium, provided the original work is properly cited. Data associated with the article are available under the terms of the Creative Commons Zero "No rights reserved" data waiver (CC0 1.0 Public domain dedication).

How to cite this article: Molgaard S, Ulrichsen M, Boggild S et al. Immunohistochemical visualization of mouse interneuron subtypes [version 1; peer review: 2 approved, 1 approved with reservations] F1000Research 2014, 3:242

https://doi.org/10.12688/f1000research.5349.1

First published: 13 Oct 2014, 3:242 https://doi.org/10.12688/f1000research.5349.1 


\section{Introduction}

Hippocampal networks are composed of a large portion of excitatory principal cells and a smaller cohort of inhibitory interneurons ${ }^{1}$. Inhibitory interneurons release $\gamma$-aminobutyric acid (GABA), which is the major inhibitory neurotransmitter in the brain. Its principal action is mediated through ubiquitous fast ionotropic $\mathrm{GABA}_{\mathrm{A}}$ receptors by increasing the membrane permeability to $\mathrm{Cl}^{-}$ions ${ }^{2}$. This inhibitory mechanism regulates the excitability of both principal cells and GABAergic interneurons. In this way, GABA is able to efficiently control the rhythms of cortical networks ${ }^{3}$, which is believed to be of critical importance for information processing ${ }^{4}$. Breakdown of these brain rhythms in neuropsychiatric disorders, such as schizophrenia, depression and bipolar disorder, is thought to involve a defective GABA system ${ }^{5}$.

Inhibitory interneurons of the dentate gyrus is a highly diverse population and early studies identified up to 21 different subtypes in this region alone ${ }^{6}$. Immunostaining against GABA have shown discrepancy when compared to in-situ hybridization against glutamate decarboxylase, indicating that some cells may express very low levels of GABA leaving this as an insufficient choice for immunostaining ${ }^{7-9}$. These 21 subtypes can be distinguished based on axonal distribution, synaptic targets, neuropeptide or calciumbinding protein content and physiological characteristics ${ }^{10}$. In order to fully characterize a subtype, all parameters must be taken into account. When immunostaining against neuropeptides or calciumbinding proteins, this is not possible, and immunostaining therefore only allows characterization of subgroups.

One such subgroup is the parvalbumin expressing interneurons. Parvalbumin-labelled cell bodies are found primarily near the granule cell layer and are most prominent at the base of the granule cell layer. However, few are also found near the border of the granule cell and molecular layers and some in the hilus as well ${ }^{10}$. Although this is considered the largest group of the subgroups in the hippocampus, in the dentate gyrus these only represent around 20\% of the total number of GABAergic interneurons as compared to around $40 \%$ in $\mathrm{CA} 1$ and $\mathrm{CA} 3^{11}$.

Several distinct populations are found that express the calciumbinding protein calretinin. Most notably, calretinin is also found in mossy cells of the hilus ${ }^{12}$, and such mossy cells are particular numerous in the ventral hilus. Calretinin is also found in axon terminals of mossy cells which creates a dense band of labelling in the inner third of the molecular layer ${ }^{13}$.

Despite labelling of mossy cells in the hilus, some GABAergic interneurons can also be found in the hilus near the granule layer ${ }^{14}$. These can often be distinguished by the more intense labelling when staining for calretinin compared to that of mossy cells.

Another subgroup is the somatostatin expressing interneurons. This subgroup comprises the largest group of GABAergic interneurons in the dentate gyrus and these are almost exclusively found within the hilus where they comprise approximately $55 \%$ of the total number of GABAergic interneurons with a slight increase from the dorsal to the ventral part of hippocampus ${ }^{15}$. As almost all somatostatin positive interneurons are found within the hilus, little labelling is found within the granule cell layer, except from a large number of axons from hilar somatostatin interneurons that project through this layer ${ }^{15,16}$.

Calbindin has been found to be present in both inhibitory and excitatory neurons with a rather strong staining of granule cells in the dentate gyrus. Misplaced granule cells found in the stratum radiatum of the CA3 subfield are often mistaken for GABAergic interneurons but these are not positive for $\mathrm{GABA}^{1}$. All other cells in the dentate gyrus should be considered GABAergic interneurons and generally stain for GABA ${ }^{1}$. A precise percentage of calbindin interneurons is not available, but around $10-12 \%$ of total number of GABAergic interneurons is considered a close estimate ${ }^{17}$. Very few calbindin positive interneurons are found in the dentate gyrus compared to the CA-regions and these are difficult to detect due to the strong staining of granule cells, but calbindin positive interneurons can be found in the stratum moleculare and hilus ${ }^{1}$.

Importantly, markers of hippocampal GABAergic interneurons do not readily apply to other regions such as the spinal cord GABAergic interneurons. The inhibitory interneurons of the spinal dorsal horn use primarily GABA and/or glycine. GABAergic interneurons are primarily located in laminae I, II and III of the dorsal horn and constitute approximately $25 \%, 30 \%$ and $40 \%$ of rat laminae I, II and III neurons, respectively ${ }^{18,19}$. The inhibitory effect of glycine is facilitated by activation of ionotropic ligand-gated glycine receptors that mediate an influx of chloride ions ${ }^{20}$ and within lamina I-III glycine immunostaining is largely restricted to GABAergic neurons $^{18,19}$

GABAergic interneurons of the spinal dorsal horn can be identified by immunostaining against, for instance, parvalbumin and the neuronal form of nitric oxide synthase (n-NOS) besides GABA and glycine. Parvalbumin is expressed by a subpopulation of spinal cord dorsal horn interneurons that co-express GABA and glycine ${ }^{21-23}$. Conversely, calretinin, somatostatin and calbindin do not co-localize with GABA in interneurons of the dorsal horn, for which reason they are thought to co-localize to excitatory interneurons ${ }^{21,23-25}$. Thus, care should be taken when extrapolating interneuron markers from one region of the CNS to another. In the present study, we have evaluated a number of different antibodies (Table 2) against GABAergic markers using both cultured neurons and tissue sections. All tested antibodies have previously been reported to recognize GABAergic interneurons both in peer-reviewed publications and by the manufacturers.

\section{Materials and methods}

All experiments were approved by the Danish Animal Experiments Inspectorate under the Ministry of Justice (Permit 2011/561-119) and carried out according to institutional and national guidelines.

For a full list of reagents and chemicals, please see Table 1.

\section{Hippocampal section preparation and immunostaining}

- Hippocampal sections. Adult C57BL/6j Bomtac (wild type (wt)) mice (Taconic), aged 8 weeks were deeply anesthetized by intraperitoneal injection of $5 \mathrm{mg} / \mathrm{ml}$ pentobarbital and perfused transcardially with cold $4 \%(\mathrm{w} / \mathrm{v})$ formaldehyde (pH 7,4, Hounisen) for five minutes. The brains were hereafter removed and post-fixed in $4 \%(\mathrm{w} / \mathrm{v})$ formaldehyde overnight at $4{ }^{\circ} \mathrm{C}$. The next day the brains were moved to $30 \%(\mathrm{w} / \mathrm{v})$ 
sucrose (Merck Millipore) for cryoprotection and left at $4{ }^{\circ} \mathrm{C}$ for 48 hours, moulded in Tissue-Tek ${ }^{\circledR}$ (Sakura) and stored at $-20^{\circ} \mathrm{C}$. Coronal hippocampal slices $(10 \mu \mathrm{m})$ were cut at $-20^{\circ} \mathrm{C}$ using a Leica CM1900 cryostat (using low-profile disposable blades 819 from Leica Biosystems) and the sections were afterwards stored at $-20^{\circ} \mathrm{C}$ until use.

- Immunostaining of tissue. Antigen epitopes shielded by formaldehyde cross-linked lysine side chains were retrieved in a heat-mediated antigen retrieval step using Target Retrieval Solution (Dako), according to manufacturers' protocol. Hereafter, the slices were washed three times in Tris-buffered saline (TBS; pH 7.4) of ten minutes intervals, and incubated in a solution of TBS containing $0.3 \%$ Triton X-100 (Applichem) and $1 \%$ bovine serum albumin (BSA; Sigma) for thirty minutes. Following a ten minute washing step in TBS, the slices were incubated with primary antibody (Table 2) in a $50 \mathrm{mM}$ Tris-based (TB) buffer solution (pH 7.4) containing 1\% BSA (Sigma) at $4^{\circ} \mathrm{C}$ in a moisturized chamber overnight. The next day, the slices were left at room temperature (RT) for one hour, and subsequently washed three times in TBS. Slices were then incubated with secondary antibody (Table 3 ) in a $50 \mathrm{mM}$ TB buffer solution containing 1\% BSA (Sigma) at RT for four hours. Finally, the coverslips were washed three times five minutes in TBS, with Hoechst ( $5 \mu \mathrm{g} / \mu \mathrm{l}$, Sigma-Aldrich) being included in the last wash. The slices were hereafter mounted using Fluorescence Mounting Medium (Dako) and stored at $4^{\circ} \mathrm{C}$. As negative controls of the immunostaining, simultaneous stainings were done using a similar protocol, except primary antibody was omitted.

\section{Spinal cord section preparation and immunostaining}

- Spinal cord sections. Adult C57BL/6j Bomtac (wt) mice aged 16 weeks were deeply anaesthetized using $4 \%$ isoflurane (IsoFlo ${ }^{\circledR}$ vet, Abbott) prior to decapitation and hydraulic spinal cord extrusion ${ }^{26}$ using ice-cold phosphate-buffered saline (PBS; $\mathrm{pH} 7.4$ ) as the extrusion liquid. Spinal cords were fixed in $4 \%(\mathrm{w} / \mathrm{v})$ paraformaldehyde (PFA; Sigma) in PBS (pH 7.4) overnight at $4{ }^{\circ} \mathrm{C}$. The spinal cords were then cryoprotected overnight by immersion in $25 \%$ (w/v) sucrose in PBS (pH 7.4) at $4^{\circ} \mathrm{C}$. Lumbar sections $2-4$ of the spinal cords were isolated and embedded in TissueTek ${ }^{\circledR}$ (Sakura) prior to freezing, which was performed by lowering the tissue into dry-ice cold isopentane (VWR BDH Prolabo ${ }^{\circledR}$ ). The tissues were stored at $-80^{\circ} \mathrm{C}$ until further use. Transverse sections of $20 \mu \mathrm{m}$ thickness were cut at $-20^{\circ} \mathrm{C}$ using the CryoJane ${ }^{\circledR}$ Tape-Transfer System (Leica Microsystems) on a Leica CM1900 cryostat (using low-profile disposable blades 819 from Leica Biosystems) and the sections were stored at $-20^{\circ} \mathrm{C}$.

- Immunostaining of tissue. This step was done similar to previously described for immunostaining of hippocampal tissue.

\section{Primary hippocampal neurons culture preparation and immunostaining}

- Culture of primary hippocampal neurons. Postnatal day 0 (P0) C57BL/6j Bomtac (wt) mice pups were sacrificed by decapitation, brains removed and hippocampi dissected into ice cold
PBS. The tissue was dissociated for thirty minutes in $20 \mathrm{U} / \mathrm{mL}$ activated papain (Worthington Biochemical Corporation). After dissociation, the tissue was washed once in DMEM (Lonza) containing $0.01 \mathrm{mg} / \mathrm{mL}$ DNaseI (Sigma) before being triturated in DMEM (Lonza) containing $0.01 \mathrm{mg} / \mathrm{mL}$ DNaseI (Sigma). After this, Neurobasal-A medium (Gibco) containing B-27 Supplement (Gibco), 2 mM GlutaMAX (Gibco), $100 \mu \mathrm{g} / \mathrm{mL}$ Primocin (Invivogen) and $20 \mu \mathrm{M}$ floxuridine + $20 \mu \mathrm{M}$ uridine (Sigma) was added to the cells and the cells were seeded on poly-D-lysine (Sigma-Aldrich) and laminin (Invitrogen) pre-coated coverslips at a density of 100.000 cells per coverslip and left for fourteen days at $37^{\circ} \mathrm{C}$ and $5 \% \mathrm{CO}_{2}$, with medium change every second day, before being fixed in PBS containing $4 \%$ PFA.

- Immunostaining of cultured hippocampal neurons. Neurons fixed in 4\% PFA was briefly washed in PBS prior to three consecutive washes in PBS containing $0.1 \%$ Triton X-100 of ten minute intervals. Hereafter, the cells were washed once in PBS before being incubated in PBS containing 10\% FBS (Gibco) for thirty minutes at RT. After this, the cells were incubated with primary antibody (Table 2) overnight at $4^{\circ} \mathrm{C}$. The next day, the immunostaining were left at RT for one hour before continuing the immunostaining protocol. Hereafter, the cells were washed three times five minutes in PBS containing $0.1 \%$ Triton-X 100. Subsequently, the cells were incubated with secondary antibodies (Table 3) for four hours at RT. The coverslips were then washed two times five minutes in PBS followed by a five minute wash in PBS containing Hoechst $(5 \mu \mathrm{g} / \mu \mathrm{l}$, Sigma-Aldrich) before being mounted using Fluorescence Mounting Medium (Dako) and stored at $4{ }^{\circ} \mathrm{C}$. As negative controls of the immunostaining, simultaneous stainings were done using a similar protocol, except primary antibody was omitted.

Confocal microscopy of hippocampal tissue, spinal cord tissue and cultured hippocampal neurons

- Confocal microscopy. The samples were analysed on a Zeiss confocal LSM 780 microscope (Carl Zeiss) using 20X/0.8 M27 and 63X/1.20 W Korr (Water immersion correction ring) objectives. Appropriate filters were used upon excitation of the different fluorophores to match their maximum fluorescence emission. The channels used were H258 and A568 and they were configured to obtain the best signal during image acquisition of the samples in order to prevent bleed through between the different probes. The range indicator was used to adjust gain and offset so acquired images were optimally held within the dynamic range of the detector. Frame size was selected to be "optimal" and an averaging of 16 was selected upon image acquisition in order to acquire an appropriate number of pixels and to achieve a maximum of signal-tonoise-ratio, respectively. Image acquisition was performed with foci adjusted with respect to the $568 \mathrm{~nm}$ fluorophores, as they were used to visualize the markers of interneurons; parvalbumin, calretinin, calbindin and somatostatin. Processing of the acquired images were performed in Zen 2011 (Carl Zeiss) Image Processing. All images presented were subjected to similar brightness and contrast adjustments. 
Table 1. List of chemicals and reagents. The use of each chemical can be found in the materials and methods section. The products are listed in alphabetic order.

\begin{tabular}{|c|c|c|c|}
\hline Reagent & Working Concentration & Manufacturer & Catalog number \\
\hline Bovine Serum Albumin (BSA) & $1 \% \mathrm{w} / \mathrm{v}$ in TBS or TB buffer & Sigma ${ }^{\circledR}$ & A4503 \\
\hline B-27 ${ }^{\circledR}$ Supplement & $1 x$ & $\begin{array}{l}\text { Gibco }{ }^{\circledast} \text { by Life } \\
\text { Technologies }\end{array}$ & $17504-044$ \\
\hline Deoxyribonuclease 1 (DNAse1) & $0.01 \mathrm{mg} / \mathrm{mL}$ & Sigma ${ }^{\circledR}$ & DN25 \\
\hline DMEM & $1 x$ & Lonza & BE12-604F/U1 \\
\hline D-PBS & $1 x$ & $\begin{array}{l}\text { Gibco }{ }^{\circledast} \text { by Life } \\
\text { Technologies }\end{array}$ & $14190-094$ \\
\hline Fetal bovine serum (FBS) & $1 x$ & $\begin{array}{l}\text { Gibco }{ }^{\circledast} \text { by Life } \\
\text { Technologies }\end{array}$ & $10270-106$ \\
\hline $\begin{array}{l}\text { Fluorescence Mounting } \\
\text { Medium }\end{array}$ & $\mathrm{n} / \mathrm{a}$ & Dako & S3023 \\
\hline $\begin{array}{l}\text { Floxuridine + } \\
\text { Uridine }\end{array}$ & $\begin{array}{l}20 \mu \mathrm{M} \\
20 \mu \mathrm{M}\end{array}$ & $\begin{array}{l}\text { Sigma }^{\circledR} \\
\text { Sigma }^{\circledR}\end{array}$ & $\begin{array}{l}\text { F0503 } \\
\text { U3750 }\end{array}$ \\
\hline Formaldehyde & $4 \%$ & Hounisen & 1000.5000 \\
\hline GlutaMAX ${ }^{\mathrm{TM}}$ Supplement & $2 \mathrm{mM}$ & $\begin{array}{l}\text { Gibco }{ }^{\circledR} \text { by Life } \\
\text { Technologies }\end{array}$ & $35050-061$ \\
\hline Hoechst & $5 \mu \mathrm{g} / \mu \mathrm{L}$ & Sigma-Aldrich ${ }^{\circledR}$ & 861405 \\
\hline IsoFlo ${ }^{\circledR}$ vet & $4 \%$ gas & Abbott & 002185 \\
\hline Iso-Pentane & $\mathrm{n} / \mathrm{a}$ & VWR BDH Prolabo ${ }^{\circledR}$ & 24872.298 \\
\hline Laminin & $20 \mu \mathrm{g} / \mathrm{mL}$ & Invitrogen & $23017-015$ \\
\hline Neurobasal-A ${ }^{\circledR}$ Medium & $\mathrm{n} / \mathrm{a}$ & $\begin{array}{l}\text { Gibco }{ }^{\circledR} \text { by Life } \\
\text { Technologies }\end{array}$ & $10888-022$ \\
\hline Pentobarbital 50 mg/mL & $5 \mathrm{mg} / \mathrm{mL}$ & $\begin{array}{l}\text { The pharmacy at Aarhus } \\
\text { University }\end{array}$ & \\
\hline Paraformaldehyde & $4 \%$ w/v in PBS, $\mathrm{pH} 7,4$ & Sigma Aldrich ${ }^{\circledR}$ & P6148 \\
\hline Papain & $20 \mathrm{U} / \mathrm{mL}$ & $\begin{array}{l}\text { Worthington Biochemical } \\
\text { Corporation }\end{array}$ & LS003126 \\
\hline Poly-D-Lysine & $0.1 \mathrm{mg} / \mathrm{mL}$ & Sigma-Aldrich ${ }^{\circledast}$ & P6407 \\
\hline Primocin $^{T M}$ & $100 \mu \mathrm{g} / \mathrm{mL}$ & Invivogen & ant-pm-2 \\
\hline Sucrose & $30 \% \mathrm{w} / \mathrm{v}$ in PBS & Merck Millipore & 1.07687 .1000 \\
\hline Target Retrieval Solution & $1 x$ & Dako & S1699 \\
\hline Tissue-Tek ${ }^{\circledast}$ O.C. TM $^{\mathrm{TM}}$ compound & $\mathrm{n} / \mathrm{a}$ & Sakura & 4583 \\
\hline Tris Base buffer (TB buffer) & $50 \mathrm{mM}$ Tris Base & Calbiochem & 648311 \\
\hline Tris-buffered saline (TBS) & $\begin{array}{l}50 \text { mM Tris Base } \\
150 \text { mM NaCL }\end{array}$ & $\begin{array}{l}\text { Calbiochem } \\
\text { Merck Millipore }\end{array}$ & $\begin{array}{l}648311 \\
1.06404 .1000\end{array}$ \\
\hline Triton $^{\circledast}$ X-100 & $\begin{array}{l}0.3 \% \text { in TBS for IHC } \\
0.1 \% \text { in PBS for ICC }\end{array}$ & Applichem & A1388 \\
\hline
\end{tabular}


Table 2. Primary antibodies used for immunostaining of ${ }^{1}$ hippocampal sections, ${ }^{2}$ hippocampal neurons and ${ }^{3}$ spinal cord sections. The pAbmAbs rating reflects the average rating of the antibodies as of October 2014.

\begin{tabular}{|c|c|c|c|c|c|c|c|c|}
\hline Antibody & Host & Clonality & Immunogen & $\begin{array}{l}\text { Dilution } \\
\text { factor }\end{array}$ & Company & $\begin{array}{l}\text { Catalog nr. } \\
\text { batch nr. }\end{array}$ & RRID & $\begin{array}{l}\text { pAbmAbs rating } \\
(1-5)\end{array}$ \\
\hline $\begin{array}{l}\text { Anti- } \\
\text { Calbindin }\end{array}$ & Rabbit & Polyclonal & $\begin{array}{l}\text { Recombinant } \\
\text { mouse } \\
\text { calbindin }\end{array}$ & $1: 500$ & Millipore & $\begin{array}{l}\text { Ab1778 } \\
2040376\end{array}$ & AB_2068336 & 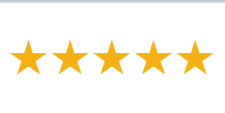 \\
\hline $\begin{array}{l}\text { Anti- } \\
\text { Calbindin }\end{array}$ & Mouse & Monoclonal & $\begin{array}{l}\text { Bovine kidney } \\
\text { calbindin-D }\end{array}$ & $1: 500$ & $\begin{array}{l}\text { Sigma- } \\
\text { Aldrich }^{\circledR}\end{array}$ & $\begin{array}{l}\text { C9848 } \\
\text { 052M4833 }\end{array}$ & AB_476894 & $x t$ \\
\hline $\begin{array}{l}\text { Anti- } \\
\text { Calbindin }{ }^{1,2}\end{array}$ & Rabbit & Monoclonal & $\begin{array}{l}\text { Chicken gut } \\
\text { calbindin } \\
\text { D-28k }\end{array}$ & $1: 200$ & Swant & $\begin{array}{l}\text { D28K } \\
07(F)\end{array}$ & $\mathrm{n} / \mathrm{a}$ & $\star$ \\
\hline $\begin{array}{l}\text { Anti- } \\
\text { Calretinin }\end{array}$ & Rabbit & Polyclonal & $\begin{array}{l}\text { Recombinant } \\
\text { rat calretinin }\end{array}$ & $1: 1000$ & Millipore & $\begin{array}{l}\text { Ab5054 } \\
20 \times \times 170\end{array}$ & AB_2068506 & 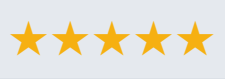 \\
\hline $\begin{array}{l}\text { Anti- } \\
\text { Calretinin }{ }^{1,2}\end{array}$ & Sheep & Polyclonal & $\begin{array}{l}\text { Native guinea } \\
\text { pig calretinin }\end{array}$ & $1: 500$ & Rockland & $\begin{array}{l}\text { 200-601-D13 } \\
28000\end{array}$ & AB_11183443 & 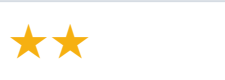 \\
\hline $\begin{array}{l}\text { Anti- } \\
\text { Calretinin }\end{array}$ & Mouse & Monoclonal & $\begin{array}{l}\text { Recombinant } \\
\text { rat calretinin }\end{array}$ & $1: 1000$ & Millipore & $\begin{array}{l}\text { Mab1568 } \\
2123143\end{array}$ & AB_94259 & 太九市太 \\
\hline $\begin{array}{l}\text { Anti- } \\
\text { Calretinin }\end{array}$ & Mouse & Monoclonal & $\begin{array}{l}\text { Recombinant } \\
\text { human } \\
\text { calretinin }\end{array}$ & $1: 200$ & Swant & $\begin{array}{l}\text { 6B3 } \\
010399\end{array}$ & AB_10000320 & $\star \star x \backslash$ \\
\hline $\begin{array}{l}\text { Anti- } \\
\text { Parvalbumin }{ }^{1-3}\end{array}$ & Rabbit & Polyclonal & $\begin{array}{l}\text { Rat } \\
\text { parvalbumin }\end{array}$ & $1: 1000$ & Abcam & $\begin{array}{l}\text { Ab11427 } \\
\text { GR101095-2 }\end{array}$ & AB_298032 & 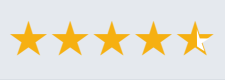 \\
\hline $\begin{array}{l}\text { Anti- } \\
\text { Parvalbumin }{ }^{1,2}\end{array}$ & Guinea pig & Polyclonal & $\begin{array}{l}\text { Recombinant } \\
\text { rat parvalbumin }\end{array}$ & $1: 250$ & $\begin{array}{l}\text { Synaptic } \\
\text { systems }\end{array}$ & $\begin{array}{l}195004 \\
195004 / 11\end{array}$ & AB_2156476 & 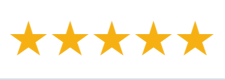 \\
\hline $\begin{array}{l}\text { Anti- } \\
\text { Parvalbumin }{ }^{1,2}\end{array}$ & Mouse & Monoclonal & $\begin{array}{l}\text { Frog muscle } \\
\text { parvalbumin }\end{array}$ & $1: 2000$ & $\begin{array}{l}\text { Sigma- } \\
\text { Aldrich }^{\circledR}\end{array}$ & $\begin{array}{l}\text { P3088 } \\
100 M 4797\end{array}$ & AB_477329 & 六市市 \\
\hline $\begin{array}{l}\text { Anti- } \\
\text { Parvalbumin } \\
\text { 1,2 }\end{array}$ & Rabbit & Polyclonal & $\begin{array}{l}\text { Synthetic } \\
\text { peptide }\end{array}$ & $1: 250$ & Millipore & $\begin{array}{l}\text { Ab15736 } \\
1869268\end{array}$ & AB_838238 & $\star \star \star x$ \\
\hline $\begin{array}{l}\text { Anti- } \\
\text { Somatostatin }\end{array}$ & Rat & Monoclonal & $\begin{array}{l}\text { Synthetic } \\
\text { peptide }\end{array}$ & $1: 1000$ & Millipore & $\begin{array}{l}\text { Mab354 } \\
2060939\end{array}$ & AB_2255365 & 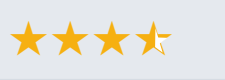 \\
\hline $\begin{array}{l}\text { Anti- } \\
\text { Somatostatin }\end{array}$ & Rabbit & Polyclonal & $\begin{array}{l}\text { Synthetic } \\
\text { human peptide }\end{array}$ & $1: 250$ & $\begin{array}{l}\text { Sigma- } \\
\text { Aldrich }^{\circledR}\end{array}$ & $\begin{array}{l}\text { SAB4502861 } \\
310328\end{array}$ & AB_10747468 & 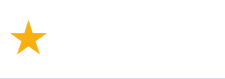 \\
\hline
\end{tabular}

Table 3. Secondary antibodies used for immunostaining of ${ }^{1}$ hippocampal sections, ${ }^{2}$ hippocampal neurons and ${ }^{3}$ spinal cord sections.

\begin{tabular}{|c|c|c|c|c|c|}
\hline Antibody & Host & Fluorescent dye & Dilution factor & Company & Catalog nr. \\
\hline$\alpha$-Rabbit IgG $(H+L)^{1-3}$ & Donkey & Alexa Fluor $^{\circledR} 568$ & $1: 300$ & Molecular probes ${ }^{\circledR}$ & A-10042 \\
\hline$\alpha$-Mouse IgG $(H+L)^{1,2}$ & Donkey & Alexa Fluor ${ }^{\circledR} 568$ & $1: 300$ & Molecular probes ${ }^{\circledR}$ & A-10037 \\
\hline$\alpha$-Sheep IgG $(H+L)^{1,2}$ & Donkey & Alexa Fluor ${ }^{\circledast} 568$ & $1: 300$ & Molecular probes ${ }^{\circledR}$ & A-21099 \\
\hline$\alpha$-Guinea Pig IgG $(H+L)^{1,2}$ & Donkey & $\mathrm{CF}^{\mathrm{TM}}$ 488A & $1: 300$ & Sigma & SAB4600033 \\
\hline$\alpha-R a t$ lgG $(H+L)^{1,2}$ & Goat & Alexa Fluor $^{\circledR} 568$ & $1: 300$ & Molecular probes ${ }^{\circledR}$ & A-11077 \\
\hline$\alpha-R a t \lg G(H+L)^{3}$ & Donkey & Alexa Fluor ${ }^{\circledR} 594$ & $1: 300$ & Molecular probes ${ }^{\circledR}$ & A-21209 \\
\hline
\end{tabular}




\section{Results and discussion}

\section{Interneurons of the hippocampus}

Initially, we screened the antibody specificity by staining of cultured hippocampal neurons, evaluating antibodies based on their ability to mark a distinct subset of neurons. Hereafter, when staining hippocampal slices, the antibodies were rated based on the expected localization and abundance of interneurons positive for the specific staining.

The localization of parvalbumin interneurons within the dentate gyrus is very well described so cells staining positive in layers where parvalbumin interneurons are not expected were considered as unspecific immunostaining. For several of the immunostainings, very little, if any, signal was obtained. However, the anti-parvalbumin ab11427 antibody from Abcam gave a clear and intense staining of parvalbumin interneurons both in culture and in hippocampal tissue sections (Figure 1 and Table 2). As the positive neurons were found in layers of the dentate gyrus, where parvalbumin positive interneurons have previously been described to be located, at an expected frequency, this was considered a specific staining and was therefore rated with 5 out of 5 stars on pAbmAbs (www.pAbmAbs.com).

Unlike parvalbumin, calretinin is found not only in interneurons but also in mossy cells within the dentate gyrus. These can often be distinguished based on the intensity of the labelling. When rating these antibodies, the correct localization of positive neurons was therefore considered not only in relation to interneurons but also to mossy cells. Both antibodies from Millipore showed high specificity

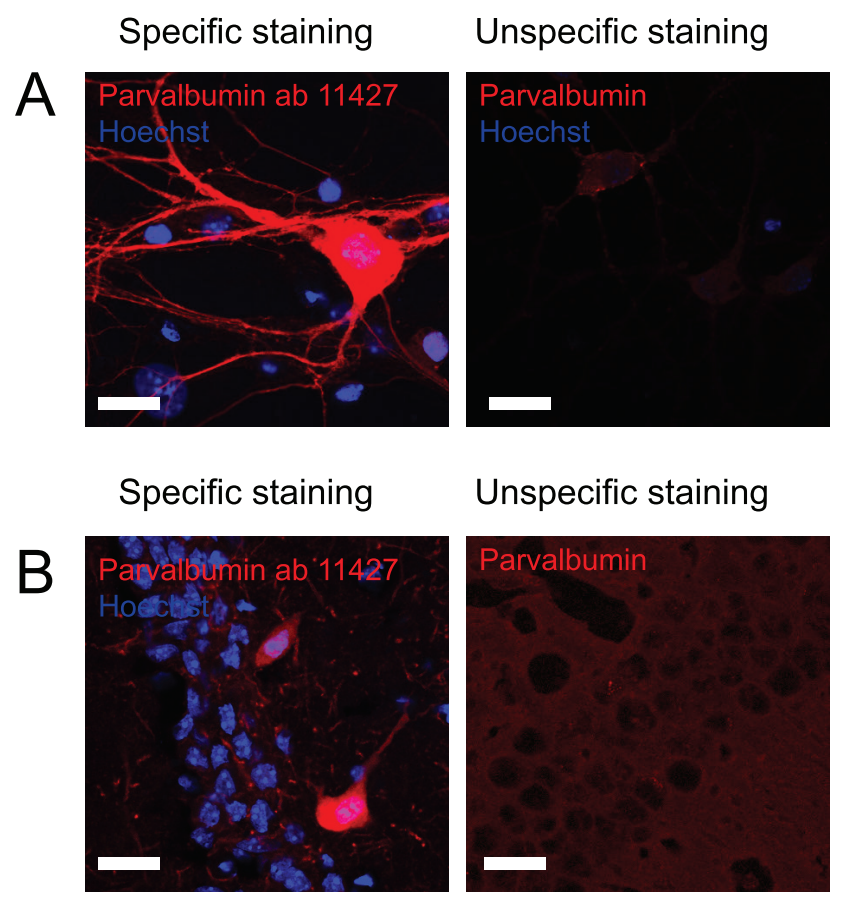

Figure 1. Staining against parvalbumin interneurons. A) shows specific and unspecific staining against parvalbumin in cultured hippocampal neurons. B) is a staining of hippocampal tissue, also showing a specific and an unspecific staining. Scale bar represents $20 \mu \mathrm{m}$. against calretinin, and especially the anti-calretinin ab5054 antibody gave a very specific staining with a high signal-to-noise ratio and was therefore given 5 out of 5 stars on pAbmAbs (Figure 2 and Table 2).

Similarly, antibodies against somatostatin were evaluated based on signal-to-noise and localization of neurons positive for somatostatin. In most cases, staining against somatostatin gave a high background with very low signal. However, using the anti-somatostatin mab364 antibody from Millipore we observed a clear staining with a good signal-to-noise ratio (Figure 3 and Table 2) and therefore it received a rating of 5 out of 5 stars. The neurons positive for somatostatin were, as expected, found in the hilus of the dentate gyrus.

Like calretinin, calbindin is also expressed by non-inhibitory cells. When looking at the dentate gyrus, expression of calbindin by principal cells within the granule cell layer gives a weak immunostaining which might seem like unspecific binding, however that is not the case. Interneurons positive for calbindin can be recognized based on the location as well as increased intensity of the immunostaining. Due to the very low number of calbindin-interneurons in the hilus, this immunostaining can be hard to detect. Many of the antibodies we tested showed very little if any difference in staining intensity between interneurons and granule cells. However, using the anti-calbindin ab1778 antibody from Millipore we were able to distinguish between interneurons and granule cells (Figure 4 and Table 2). Since this antibody also shows very little background staining it was rated 5 stars on pAbmAbs.
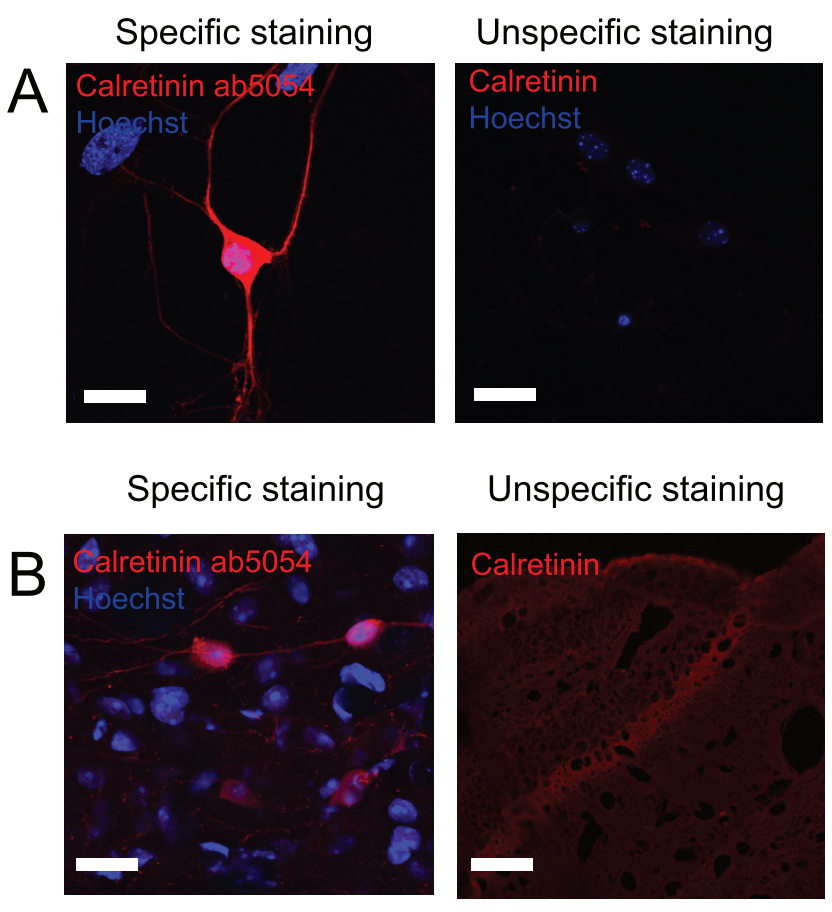

\section{Unspecific staining}

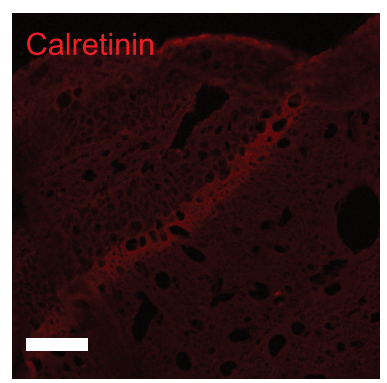

Figure 2. Staining against calretinin. A) shows specific and unspecific staining against calretinin in cultured hippocampal neurons. B) is a staining of hippocampal tissue, also showing a specific and an unspecific staining. Scale bar represents $20 \mu \mathrm{m}$. 


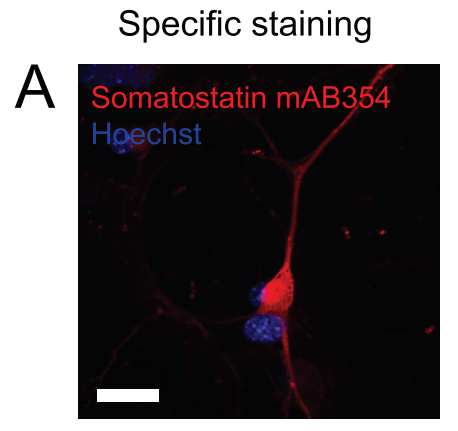

Unspecific staining

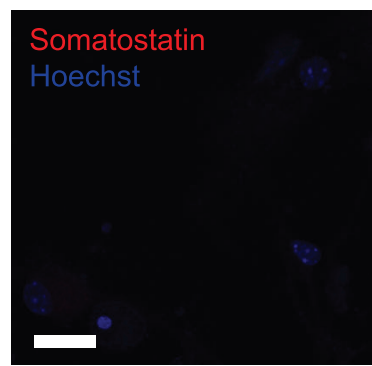

Specific staining

$\mathrm{B}$

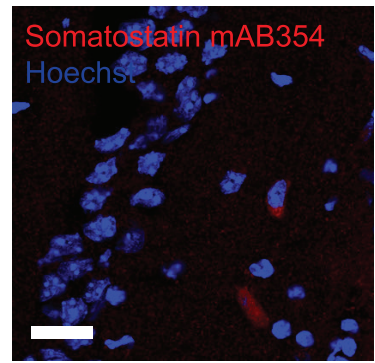

Unspecific staining

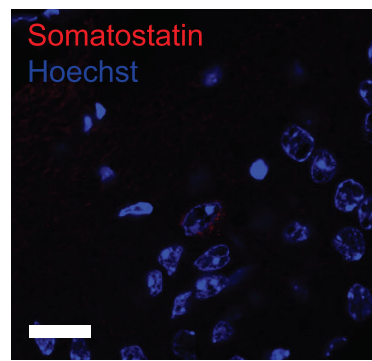

Figure 3. Staining against somatostatin. A) shows specific and unspecific staining against calretinin in cultured hippocampal neurons. B) is a staining of hippocampal tissue, also showing a specific and an unspecific staining. Scale bar represents $20 \mu \mathrm{m}$.

\section{Interneurons of the spinal cord}

Parvalbumin positive cells of the spinal cord dorsal horn also represent a subgroup of GABAergic interneurons and immunostaining against parvalbumin can accordingly be used as a marker of GABAergic interneurons. When staining against parvalbumin with the anti-parvalbumin ab11427 antibody from Abcam they appeared to be largely restricted to laminae II-III of the dorsal horn, which is in accordance with previous findings ${ }^{27}$. The parvalbumin positive cells of laminae II-III were rather small and showed intense immunoreactivity in the nucleus and in the soma, as previously described $^{22}$, making it easy to distinguish them from background staining. This antibody also appeared to stain neuronal processes of the dorsal horn and columns as well as the nuclei of ventral horn motor neurons, as previously described ${ }^{27-29}$. Although this antibody can be used to identify intense immunoreactive parvalbumin positive cells and function as a great marker of the parvalbumin positive subpopulation of GABAergic neurons of the spinal dorsal horn in locations previously described, it showed some background staining of spinal cord cryo-sections and was rated 4 out of 5 stars on pAbmAbs.

Unlike interneurons of the hippocampus, calretinin can only be used as a marker of interneurons that do not contain GABA in the spinal $\operatorname{cord}^{24}$. The anti-calretinin AB5054 antibody from Merck Millipore works well for IHC of spinal cord cryo-sections (data not shown) and was rated 5 out of 5 stars on pAbmAbs, as it showed very low background staining and intense staining of a dense well-defined band of small calretinin immunoreactive cells in the superficial
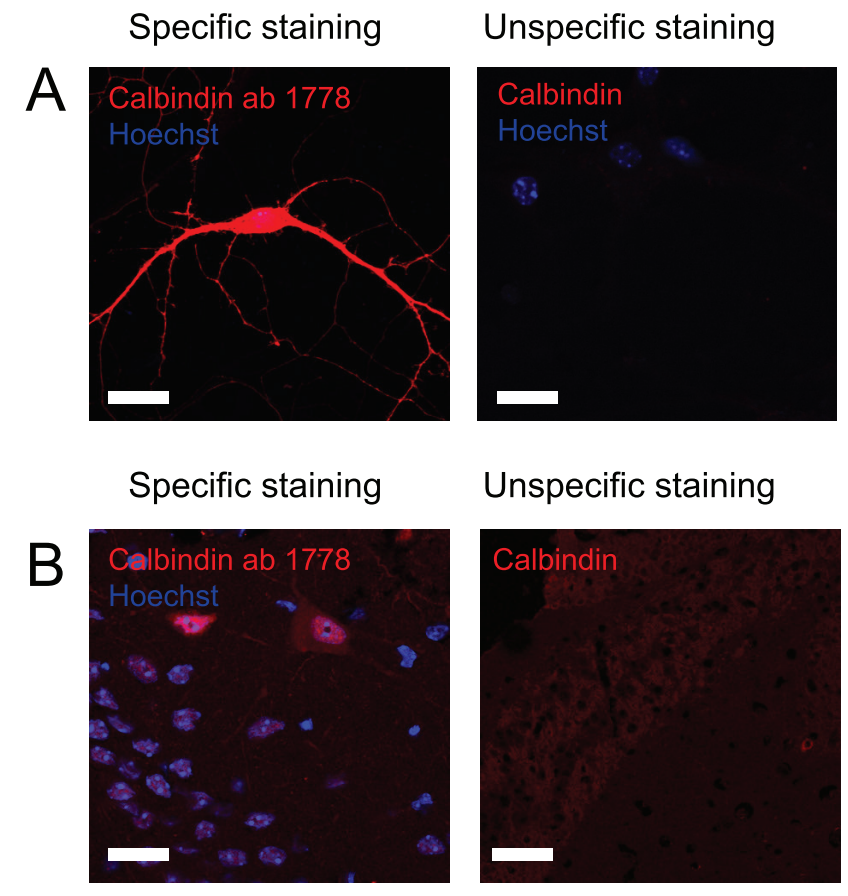

\section{Unspecific staining}

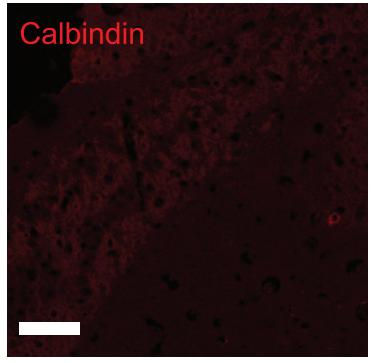

Figure 4. Staining against calbindin. A) shows specific and unspecific staining against calbindin in cultured hippocampal neurons. B) is a staining of hippocampal tissue, also showing a specific and an unspecific staining. Scale bar represents $20 \mu \mathrm{m}$.

laminae of the dorsal horn and of large cells in lamina V-VI. These observations correlates with previous description of calretinin immunoreactivity in the spinal $\operatorname{cord}^{24}$, and indicates high specificity of the antibody.

In contrast to IHC of hippocampal sections with the anti-somatostatin MAB354 antibody from Millipore, this antibody gave a low signal when staining against somatostatin on spinal cord sections. Using this antibody, it was difficult to identify somatostatin positive cells in the spinal dorsal horn that otherwise previously have been described to be located in a dense band in lamina II of rat $^{25}$ and mouse ${ }^{21}$ spinal dorsal horn. Therefore, the antibody was rated 2 out of 5 stars on pAbmAbs. This antibody was rated 5 out of 5 for the hippocampal staining, leading to an average rating of 3.5 on pAbmAbs.

Like calretinin and somatostatin, calbindin can be used as a marker of spinal dorsal horn interneurons that do not contain $\mathrm{GABA}^{23}$. A dense band of calbindin immunoreactivity has previously been shown in lamina II and a more sparse band in lamina I, III and IV of the rat spinal dorsal horn ${ }^{23}$. This localization of calbindin immunoreactivity is also seen when using the anti-calbindin AB1778 antibody from Merck Millipore (data not shown). Also, the cells that constitute the central channel and motor neurons of the ventral horn also show calbindin immunoreactivity when staining with this antibody, which is in accordance with previously finding ${ }^{28,30}$. The antibody showed very intense staining of cytoplasm and nuclei, as well as processes of the outer lamina of the dorsal horn and showed 
low background staining. On the basis of these observations the antibody was rated 5 out of 5 stars on pAbmAbs.

\section{Dataset 1. Interneurons of hippocampus and spinal cord}

http://dx.doi.org/10.5256/f1000research.5349.d36682

The raw microscopy images for both hippocampal and spinal cord interneurons are shown in the .czi files provided.

\section{Conclusion}

In conclusion, staining against interneurons can be a very tedious task and great consideration is needed to ensure that it is actually only interneurons that are being stained. Optimizing protocols for immunostaining can be a, not only time consuming, but also an expensive task in a market full of different antibody options. By creating an information-sharing platform, pAbmAbs allows for a fast and cost-free screening of the current antibodies out there and thereby ensures that only the best antibodies are used. In the current study, we tested antibodies against parvalbumin, calretinin, calbindin and somatostatin, all markers of hippocampal GABAergic interneurons, both in culture and on hippocampal and spinal cord tissue. These antibodies were rated on specificity, and signal-to-noise ratio, for both tissue and culture. When immunostaining tissue, we also looked at the localization of positive cells within the tissue to ensure that only cells in the expected layers of the tissue stained positive for the GABAergic markers. When staining against parvalbumin we found that out of four different antibodies, the antiparvalbumin ab11427 antibody from Abcam got a high score as it stained cells specifically with a high signal-to-noise ratio with the expected localization within the tissue. When staining against calretinin, the anti-calretinin ab5054 antibody from Millipore obtained the highest score on pAbmAbs. This antibody gave a very nice signal-to-noise ratio compared to the other antibodies tested. The anti-somatostatin mab354 antibody from Millipore was found to be the best antibody for stainings against somatostatin. Similar to the other antibodies with high pAbmAbs ratings, this also had a high signal-to-noise ratio compared to other antibodies tested. Finally, the anti-calbindin ab1178 antibody from Millipore got the highest rating out of the antibodies tested against this GABAergic subgroup. Overall, the antibody tested gave varying results when using our protocols. The specificities of the antibodies are therefore reflected on pAbmAbs which, by serving as a database, will help fast and cost-free evaluation of antibodies.

\section{Data availability}

F1000Research: Dataset 1. Interneurons of hippocampus and spinal cord, 10.5256/f1000research.5349.d36682 $2^{31}$

\section{Author contributions}

SM and SG conceived this study. SM designed the experiments. SM, MU and SBH carried out the research. SG, JRN and CV contributed to the design of the experiment and expertise in immunohistochemistry. SM, SG and MU contributed to the preparation of the manuscript. All authors were involved in the revision of the draft manuscript and have agreed to the final content.

\section{Competing interests}

No competing interests were disclosed.

\section{Grant information}

This study was funded by the Lundbeck Foundation, Danish Medical Research Council, Fonden til forskning af sindslidelser and Agnes og Poul Friis Fond.

\section{Acknowledgements}

We thank Helene Andersen, Anja Aagaard and Benedicte Vestergaard for excellent technical assistance.
1. Freund TF, Buzsaki G: Interneurons of the hippocampus. Hippocampus. 1996 6(4): 347-470.

PubMed Abstract | Publisher Full Text

2. Farrant $M$, Nusser $Z$ : Variations on an inhibitory theme: phasic and tonic activation of GABA(A) receptors. Nat Rev Neurosci. 2005; 6(3): 215-29. PubMed Abstract | Publisher Full Text

3. Wang XJ, Buzsaki G: Gamma oscillation by synaptic inhibition in a hippocampal interneuronal network model. J Neurosci. 1996; 16(20): 6402-13. PubMed Abstract

4. Buzsaki G, Draguhn A: Neuronal oscillations in cortical networks. Science. 2004; 304(5679): 1926-1929.

PubMed Abstract | Publisher Full Text

5. Benes FM, Berretta S: GABAergic interneurons: implications for understanding schizophrenia and bipolar disorder. Neuropsychopharmacology. 2001; 25(1): 1-27. PubMed Abstract | Publisher Full Text

6. Amaral DG: A Golgi study of cell types in the hilar region of the hippocampus in the rat. J Comp Neurol. 1978; 182(4 Pt 2): 851-914.

PubMed Abstract | Publisher Full Text

7. Erlander MG, Tillakaratne NJ, Feldblum S, et al.: Two genes encode distinct glutamate decarboxylases. Neuron. 1991; 7(1): 91-100. PubMed Abstract | Publisher Full Text

8. Ribak CE, Vaughn JE, Saito K: Immunocytochemical localization of glutamic acid decarboxylase in neuronal somata following colchicine inhibition of axonal transport. Brain Res. 1978; 140(2): 315-32. PubMed Abstract | Publisher Full Text

9. Jinno S, Aika Y, Fukuda T, et al:: Quantitative analysis of GABAergic neurons in the mouse hippocampus, with optical disector using confocal laser scanning microscope. Brain Res. 1998; 814(1-2): 55-70.

PubMed Abstract | Publisher Full Text

10. Somogyi $\mathrm{P}, \mathrm{Klausberger} \mathrm{T}$ : Defined types of cortical interneurone structure space and spike timing in the hippocampus. J Physiol. 2005; 562(Pt 1): 9-26. PubMed Abstract | Publisher Full Text | Free Full Text

11. Ribak $C E$, Nitsch R, Seress L: Proportion of parvalbumin-positive basket cells in the GABAergic innervation of pyramidal and granule cells of the rat hippocampal formation. J Comp Neurol. 1990; 300(4): 449-61. PubMed Abstract | Publisher Full Text

12. Blasco-Ibanez JM, Freund TF: Distribution, ultrastructure, and connectivity of calretinin-immunoreactive mossy cells of the mouse dentate gyrus. Hippocampus. 1997; 7(3): 307-20. PubMed Abstract | Publisher Full Text

13. Fujise $\mathrm{N}$, Liu $\mathrm{Y}$, Hori $\mathrm{N}$, et al: Distribution of calretinin immunoreactivity in the mouse dentate gyrus: II. Mossy cells, with special reference to their dorsoventral difference in calretinin immunoreactivity. Neuroscience. 1998; 82(1): 181-200.

PubMed Abstract | Publisher Full Text 
14. Gulyas AI, Hajos N, Freund TF: Interneurons containing calretinin are specialized to control other interneurons in the rat hippocampus. J Neurosci. 1996; 16(10): 3397-411.

PubMed Abstract

15. Jinno S, Kosaka T: Patterns of expression of neuropeptides in GABAergic nonprincipal neurons in the mouse hippocampus: Quantitative analysis with optical disector. J Comp Neurol. 2003; 461(3): 333-49. PubMed Abstract | Publisher Full Text

16. Katona I, Acsady L, Freund TF: Postsynaptic targets of somatostatin-immunoreactive interneurons in the rat hippocampus. Neuroscience. 1999; 88(1): 37-55. PubMed Abstract | Publisher Full Text

17. Gulyas Al, Toth $\mathrm{K}$, Danos $\mathrm{P}$, et al.: Subpopulations of GABAergic neurons containing parvalbumin, calbindin D28k, and cholecystokinin in the rat hippocampus. J Comp Neurol. 1991; 312(3): 371-8. PubMed Abstract | Publisher Full Text

18. Todd AJ, Sullivan AC: Light microscope study of the coexistence of GABAlike and glycine-like immunoreactivities in the spinal cord of the rat. $J$ Comp Neurol. 1990; 296(3): 496-505.

PubMed Abstract | Publisher Full Text

19. Polgar E, Hughes DI, Riddell JS, et al:: Selective loss of spinal GABAergic or glycinergic neurons is not necessary for development of thermal hyperalgesia in the chronic constriction injury model of neuropathic pain. Pain. 2003 104(1-2): 229-39. PubMed Abstract | Publisher Full Text

20. Zeilhofer HU: The glycinergic control of spinal pain processing. Cell Mol Life Sci. 2005; 62(18): 2027-35.

PubMed Abstract | Publisher Full Text

21. Heinke B, Ruscheweyh R, Forsthuber L, et al.: Physiological, neurochemical and morphological properties of a subgroup of GABAergic spinal lamina II neurones identified by expression of green fluorescent protein in mice. J Physiol. 2004; 560(Pt 1): 249-66.

PubMed Abstract | Publisher Full Text | Free Full Text

22. Laing I, Todd AJ, Heizmann CW, et al.: Subpopulations of GABAergic neurons in laminae I-III of rat spinal dorsal horn defined by coexistence with classical transmitters, peptides, nitric oxide synthase or parvalbumin. Neuroscience. 1994; 61(1): 123-32.

PubMed Abstract | Publisher Full Text
Antal M, Polgár E, Chalmers J, et al.: Different populations of parvalbumin- and calbindin-D28k-immunoreactive neurons contain GABA and accumulate 3H-Daspartate in the dorsal horn of the rat spinal cord. J Comp Neurol. 1991; 314(1): 114-24.

PubMed Abstract | Publisher Full Text

24. Ren K, Ruda MA: A comparative study of the calcium-binding proteins calbindin-D28K, calretinin, calmodulin and parvalbumin in the rat spinal cord. Brain Res Brain Res Rev. 1994; 19(2): 163-79.

PubMed Abstract | Publisher Full Text

25. Proudlock F, Spike RC, Todd AJ: Immunocytochemical study of somatostatin, neurotensin, GABA, and glycine in rat spinal dorsal horn. J Comp Neurol. 1993; 327(2): 289-97.

PubMed Abstract | Publisher Full Text

26. Meikle AD, Martin AH: A rapid method for removal of the spinal cord. Stain Technol. 1981; 56(4): 235-7.

PubMed Abstract | Publisher Full Text

27. Hughes DI, Sikander S, Kinnon CM, et al.: Morphological, neurochemical and electrophysiological features of parvalbumin-expressing cells: a likely source of axo-axonic inputs in the mouse spinal dorsal horn. J Physiol. 2012; 590(Pt 16) 3927-51.

PubMed Abstract | Publisher Full Text | Free Full Text

28. Ince $\mathrm{P}$, Stout $\mathrm{N}$, Shaw $\mathrm{P}$, et al.: Parvalbumin and calbindin $\mathrm{D}-\mathbf{2 8 k}$ in the human motor system and in motor neuron disease. Neuropathol Appl Neurobiol. 1993; 19(4): 291-9.

PubMed Abstract | Publisher Full Text

29. Antal M, Freund TF, Polgar E: Calcium-binding proteins, parvalbumin- and calbindin-D 28k-immunoreactive neurons in the rat spinal cord and dorsal roo ganglia: a light and electron microscopic study. J Comp Neurol. 1990; 295(3): 467-84.

PubMed Abstract | Publisher Full Text

30. Holm MM, Nieto-Gonzalez JL, Vardya I, et al:: Mature BDNF, but not proBDNF, reduces excitability of fast-spiking interneurons in mouse dentate gyrus. J Neurosci. 2009; 29(40): 12412-8. PubMed Abstract | Publisher Full Text

31. Molgaard S, Ulrichsen M, Boggild S, et al:: Dataset 1. Interneurons of hippocampus and spinal cord. F1000Research. 2014. Data Source 


\section{Open Peer Review}

\section{Current Peer Review Status:}

\section{Version 1}

Reviewer Report 21 October 2014

https://doi.org/10.5256/f1000research.5710.r6402

(C) 2014 Leung $\mathbf{M}$. This is an open access peer review report distributed under the terms of the Creative Commons Attribution License, which permits unrestricted use, distribution, and reproduction in any medium, provided the original work is properly cited.

\section{Mei Yee Leung}

St John's Laboratory Ltd., London, UK

This is an informative, concise article with clear aims that highlights the potential difficulties in selecting the right antibodies for specific cell types and research applications. In this study, the authors systematically tested commercial antibodies against calbindin, calretinin, parvalbumin and somatostatin - markers of GABAergic interneuron subtypes. Of the 13 antibodies tested, only 4 were deemed reliable and useful for characterizing these subtypes in mouse brain.

The authors' rigorous approach in selecting the right antibodies is commendable, a fact which often goes unnoticed in publications. The ranking of antibody performance in pAbmAbs, a reviewbased platform is a much needed resource for scientists whose research depends on the validity of the antibodies.

As someone not in this research area, I found the manuscript scientifically well construed and the rationale easy to follow. It is noteworthy that this study by Molgaard et al. adds to the understanding of GABAergic subtypes in the mouse hippocampus and spinal cord, information which is sparse in the literature. In addition, by demonstrating specific staining of these markers, they have confirmed previously reported localization of these cells.

\section{A few comments/suggestions}

Would a change in the title be more appropriate? e.g. Immunofluorescent instead of immunohistochemical

Is there any reason why the age of the mouse used for hippocampal staining and that for spinal cord staining is different?

It would add value to this paper is images of spinal cord staining was also shown

Although the without primary images are very clean, using these antibodies on tissues not known to express these targets would be a more superior negative control

Could the authors offer an explanation for why the polyclonal antibodies appear to perform better than the monoclonals?

To obtain better idea of reproducibility, it would be good to give an indication of how many 
times the experiment was performed and how many sections were stained per experiment

Competing Interests: No competing interests were disclosed.

I confirm that I have read this submission and believe that I have an appropriate level of expertise to confirm that it is of an acceptable scientific standard.

Author Response 12 Nov 2014

Simon Molgaard, Department of Biomedicine, Aarhus University, Aarhus, Denmark

"Would a change in the title be more appropriate? e.g. Immunofluorescent instead of immunohistochemical"

\section{Reply: OK}

"Is there any reason why the age of the mouse used for hippocampal staining and that for spinal cord staining is different?"

Reply: No particular reason. The expression of GABAergic markers in the hippocampus and spinal cord of adult animals is expected to be fairly constant throughout adulthood.

"It would add value to this paper is images of spinal cord staining was also shown"

Reply: Done

"Although the without primary images are very clean, using these antibodies on tissues not known to express these targets would be a more superior negative control"

Reply: This point may rely on a possible misunderstanding. The images in the paper denoted "Unspecific staining" refers to stainings using primary antibodies for which no specific signal was observed. We have changed the legends to make this more clear.

"Could the authors offer an explanation for why the polyclonal antibodies appear to perform better than the monoclonals?"

Reply: We have no clear answer to this but it may be that polyclonal antibodies generally give a higher signal compared monoclonal antibodies due to the presence of multiple epitopes.

"To obtain better idea of reproducibility, it would be good to give an indication of how many times the experiment was performed and how many sections were stained per experiment"

Reply: This is now stated in the Methods section.

Competing Interests: No competing interests were disclosed. 
Reviewer Report 17 October 2014

https://doi.org/10.5256/f1000research.5710.r6403

(C) 2014 Rantamäki T. This is an open access peer review report distributed under the terms of the Creative Commons Attribution License, which permits unrestricted use, distribution, and reproduction in any medium, provided the original work is properly cited.

\section{Tomi PJ Rantamäki}

Neuroscience Center, University of Helsinki, Helsinki, Finland

Molgaard et al. have investigated the suitability of various commercially available antibodies for the identification of GABAergic interneurons in mice. Among 13 tested antibodies against calbindin (3), calretinin (4), parvalbumin (4) and somatostatin (2), the authors found 1-2 antibodies per each marker that produced high quality, sensitive and specific staining in mouse brain sections and cultured hippocampal neurons obtained from PO mouse pups. Their findings remind us about the tediousness of immunostainings in general and challenges about the identification of proper antibody and antibody conditions suitable for high quality research. Although the antibodies have not been investigated in all possible experimental conditions (e.g. fixation protocols, dilutions), the study provides very valuable reference information for researchers aiming to investigate GABAergic markers in mice.

In general the manuscript has been written and constructed well. Abstract nicely describes the summary of the study. The introduction provides very good background knowledge for the reader (incl. relevant citations). The methods section is described in a manner that allows scientific reproduction efficiently. Tables are clear and useful. Overall the representative figures are good but the paper would benefit with more comprehensive set of immunostainings (as main figures).

I have few minor comments/questions:

GABAergic interneurons are considered as small neuronal population in the text. In respect to glutamatergic neurons this is indeed the case, but overall I consider $20 \%$ quite a significant fraction (cf. monoaminergic neurons).

The authors could have clarified what is "pAbmAbs" in the abstract.

In the Introduction the authors state that breakdown of cortical network rhythms underlie neuropsychiatric disorders. I would rather say that alterations in cortical network rhythms in specific brain networks may underlie neuropsychiatric disorders.

The authors could have explained that glutamate decarboxylase is expressed in GABAergic neurons and it synthesizes GABA (Introduction, first and second paragraph).

The authors could have described the gender and amount of adult mice used for the study. Moreover, where all the antibodies tested in specimens derived from same conditions (e.g. same animal).

I would have used "sections" rather than "slices" throughout the paper.

Table 2. would be even more clear if the antibodies against the four different markers would have been divided from each other more clearly (e.g. using different background colors).

Why there appears no Hoechst staining in some of the unspecific stainings? 
Why the authors choose not to show the representative figures from spinal cord?

The authors could have emphasized that the quality of polyclonal antibodies is significantly determined by the lot/batch. This should be kept in mind when reproducing the findings. Figure legends should have been clearer. In optimal case, the reader understands the figures thoroughly without the main text (e.g. age of cultures).

It would have been very useful to test, at least selected, antibodies in rats as well (brain sections, culture)

Competing Interests: No competing interests were disclosed.

\section{I confirm that I have read this submission and believe that I have an appropriate level of} expertise to confirm that it is of an acceptable scientific standard.

\section{Author Response 12 Nov 2014}

Simon Molgaard, Department of Biomedicine, Aarhus University, Aarhus, Denmark

"GABAergic interneurons are considered as small neuronal population in the text. In respect to glutamatergic neurons this is indeed the case, but overall I consider $20 \%$ quite a significant fraction (cf. monoaminergic neurons)."

Reply: Comment well taken. The word "small" has now been removed from the abstract.

"The authors could have clarified what is "pAbmAbs" in the abstract."

Reply: This has been added to abstract.

"In the Introduction the authors state that breakdown of cortical network rhythms underlie neuropsychiatric disorders. I would rather say that alterations in cortical network rhythms in specific brain networks may underlie neuropsychiatric disorders."

Reply: We agree. The text is now changed accordingly.

"The authors could have explained that glutamate decarboxylase is expressed in GABAergic neurons and it synthesizes GABA (Introduction, first and second paragraph)."

Reply: This has now been clarified in the introduction.

"The authors could have described the gender and amount of adult mice used for the study. Moreover, where all the antibodies tested in specimens derived from same conditions (e.g. same animal)."

Reply: A paragraph has been added to the Methods clarifying these issues.

"I would have used "sections" rather than "slices" throughout the paper."

Reply: This has now been corrected. 
"Table 2. would be even more clear if the antibodies against the four different markers would have been divided from each other more clearly (e.g. using different background colors)."

Reply: Although we agree that a color-code would be desirable, we feel that the current table is sufficiently clear.

"Why there appears no Hoechst staining in some of the unspecific stainings?"

Reply: We apologize for the lack of clarity regarding this issue. The "unspecific" images with Hoechst are shown when we observed no signal at all. The "unspecific" images without Hoechst are shown when staining was present but distributed in an unspecific manner.

"Why the authors choose not to show the representative figures from spinal cord?"

Reply: The images are already included in the data availability section.

"The authors could have emphasized that the quality of polyclonal antibodies is significantly determined by the lot/batch. This should be kept in mind when reproducing the findings."

Reply: Good point. In this regard we will refer to the article in the antibody validation collection by Dr Jan Voskuil.

"Figure legends should have been clearer. In optimal case, the reader understands the figures thoroughly without the main text (e.g. age of cultures)."

Reply: The figure legends have now been improved

"It would have been very useful to test, at least selected, antibodies in rats as well (brain sections, culture)"

Reply: We agree but as stated in the title we have only used mouse.

Competing Interests: No competing interests were disclosed.

Reviewer Report 14 October 2014

\section{https://doi.org/10.5256/f1000research.5710.r6401}

(C) 2014 Lowell S. This is an open access peer review report distributed under the terms of the Creative Commons Attribution License, which permits unrestricted use, distribution, and reproduction in any medium, provided the original work is properly cited.

\section{? Sally Lowell}


MRC Centre for Regenerative Medicine, Institute for Stem Cell Research, School of Biological Sciences, University of Edinburgh, Edinburgh, UK

The authors of this paper set out to identify antibodies that can be used to identify particular subtypes of GABAergic neurons within the mouse hippocampus. They explain that many of the antibodies that they have tested for this purpose do not seem to work, and they present data for those antibodies that they did find to be useful for this purpose. This article could therefore save readers a lot of wasted effort and money in identifying useful antibodies for their own studies in this area.

The article starts with a nice overview of the different subtypes of GABAergic neurons and the markers that are commonly used to characterise them. I am not an expert in this area so I cannot review the accuracy of the information, but I did find it to be concise and useful introduction.

There are a few issues that could be addressed to improve the results section of the article.

1. Figure legends should explain what "unspecific staining" refers to. Does this mean secondary only control? If so then this form of labelling could be misleading as non-specific binding of the primary antibody will not be picked up by a secondary-antibody-only control.

2. Why are there no Hoechst positive cells in some of the 'unspecific staining' panels?

3. The evidence that these antibodies are specific to particular subtypes of neurons comes mainly from the observation that their staining pattern is restricted to the expected regions of the hippocampus. However the figures as presented do not make this clear. Is it possible to provide a clearer demonstration of these restricted expression domains on hippocampus sections? Perhaps it would be helpful to see an accompanying diagram showing the expected distribution of each marker on these sections?

4. In Fig 3B, the 'specific staining' of antibody mAB354 is barely visible so it is difficult to assess whether there is a real difference between signal and background.

5. The article reports results from immunostaining of the spinal cord, but no figures are presented to support the authors' findings. It would be helpful to see these images.

General comments: The article is written clearly and concisely, but would benefit from being proof-read for minor grammatical errors.

Competing Interests: No competing interests were disclosed.

I confirm that I have read this submission and believe that I have an appropriate level of expertise to confirm that it is of an acceptable scientific standard, however I have significant reservations, as outlined above.

Author Response 12 Nov 2014

Simon Molgaard, Department of Biomedicine, Aarhus University, Aarhus, Denmark

"Figure legends should explain what "unspecific staining" refers to. Does this mean secondary 
only control? If so then this form of labelling could be misleading as non-specific binding of the primary antibody will not be picked up by a secondary-antibody-only control."

Reply: The figure legends have been changed to make this more clear.

"Why are there no Hoechst positive cells in some of the 'unspecific staining' panels?"

Reply: We apologize for the lack of clarity regarding this issue. The "unspecific" images with Hoechst are shown when we observed no signal at all. The "unspecific" images without Hoechst are shown when staining was present but distributed in an unspecific manner.

"The evidence that these antibodies are specific to particular subtypes of neurons comes mainly from the observation that their staining pattern is restricted to the expected regions of the hippocampus. However the figures as presented do not make this clear. Is it possible to provide a clearer demonstration of these restricted expression domains on hippocampus sections? Perhaps it would be helpful to see an accompanying diagram showing the expected distribution of each marker on these sections?"

Reply: The interneuron subtype distribution is presently used in a qualitative manner to validate whether positive staining localizes in the expected and with an expected frequency in the dentate gyrus of the hippocampus. Quantitative assessment of interneuron number using for example stereology is not feasible in the present study.

"In Fig 3B, the 'specific staining' of antibody mAB354 is barely visible so it is difficult to assess whether there is a real difference between signal and background."

Reply: We agree that the staining is weaker; however it is still distinct and specific.

"The article reports results from immunostaining of the spinal cord, but no figures are presented to support the authors' findings. It would be helpful to see these images."

Reply: The images are already included in the data availability section.

Competing Interests: No competing interests were disclosed. 
The benefits of publishing with F1000Research:

- Your article is published within days, with no editorial bias

- You can publish traditional articles, null/negative results, case reports, data notes and more

- The peer review process is transparent and collaborative

- Your article is indexed in PubMed after passing peer review

- Dedicated customer support at every stage

For pre-submission enquiries, contact research@f1000.com 